\title{
First record of trace fossils from the Oxfordian Argiles rouges de Kheneg Formation (Tiaret, northwestern Algeria)
}

\author{
Mourad Belaid ${ }^{(1,2) *}$, Amine Cherif(1,3)*, Olev Vinn ${ }^{(4)}$ and Mohammed Nadir Naimi(1,3) \\ ${ }^{1}$ Kasdi-Merbah University, Faculty of Hydrocarbons, Renewable Energies, Earth Sciences and Universe, Department of Earth Sciences and Universe, Ghardaïa Road, \\ Ouargla, 3000, Algeria ( ${ }^{*}$ corresponding author) \\ ${ }^{2}$ Kasdi-Merbah University, Laboratory of Underground Reservoirs: Petroleum, Gas and Aquifers; (belaid.mourad@univ-ouargla.dz) \\ ${ }^{3}$ Kasdi-Merbah University, Laboratory of Geology of Sahara, Algeria; acherif11@gmail.com (Amine Cherif), mohammednadirnaimi@gmail.com (Mohammed Nadir Naimi) \\ ${ }^{4}$ University of Tartu, Department of Geology, , Ravila 14A, 50411 Tartu, Estonia; (olev.vinn@ut.ee)
}

doi: $10.4154 / g c .2020 .10$

Article history:

Manuscript received April 25, 2020

Revised manuscript accepted June 30, 2020

Available online June 29, 2020

Keywords: Oxfordian, Kheneg, Algeria, Trace fossil, Offshore

\begin{abstract}
Three main facies associations FA-1 to FA-3 occur in the Oxfordian Argiles rouges de Kheneg Formation in northwestern Algeria. They correspond respectively to the deeper part of a mixed siliciclastic-carbonate shelf, upper shoreface and offshore transition-lower offshore. The trace fossil association of the Argiles rouges de Kheneg Formation contains fifteen ichnogenera and is moderately diverse for the Upper Jurassic. The formation contains diverse and abundant deep water or dominantly deep water trace fossils (i.e. Belorhaphe, Chondrites, Helminthopsis, Nereites, Megagrapton). They indicate that a part of the formation was deposited in offshore transition to lower offshore environments.
\end{abstract}

\section{INTRODUCTION}

The studied Upper Jurassic outcrops are located to the north of the town of Tiaret on the boundary of the southern Tellian domain (Fig. 1). The uppermost Jurassic deposits are distributed in North Africa along the southern margin of the former Tethys Ocean. In northwestern Algeria, the Oxfordian strata stretch over the Tellian Atlas and are named as the Ammonitico rosso de Frid and Argiles rouges de Kheneg (ATROPS \& BENEST, 1994), in the Oran and Arzew mountains (northern Tell) they are known as the Upper Oxfordian "Grès chocolatés” and eventually as "l'ensemble détritique à ostracodes” in the Tessala Mountains (FENET, 1975). In the High Plateaus Oxfordian rocks have been either referred to the "Argiles de Saïda" in the Tlemcenian domain (AUGIER, 1967; ELMI \& BENEST, 1978; CHERIF et al., 2015, 2018; HALAMSKI \& CHERIF, 2017), or as the "Grès de Sidi Saâdoun” and “Argiles de Faïdja” (CARATINI, 1970; ATROPS \& BENEST, 1981).

The Argiles rouges de Kheneg Formation is composed of red marly limestone in the lower part, thick sandstone in the middle, and red to green clay-limestone-sandstone intercalations in the upper part. The best exposures are located in the Oued Kheneg and Aïn El Hamra areas (Fig. 1). They have been mapped and investigated since the late $19^{\text {th }}$ century (e.g., WELSCH, 1890; POLVÈCHE, 1960; TCHOUMATCHENCO \& KHRISCHEV, 1992). So far, these deposits had never been described from ichnological and sedimentology points of view.

The present paper presents the first ichnologic and sedimentological study of the Oxfordian deposits exposed at Oued Kheneg and Aïn El Hamra (north of Tiaret). Our contribution provides a list of ichnotaxa and a facies inventory that aid the interpretation of the depositional environment.

\section{GEOGRAPHICAL AND GEOLOGICAL FRAME- WORK}

Geographically, the study site belongs to the northern domain of Algeria called "Alpine Algeria", which consists of three domains comprising young mountains formed during the Alpine orogeny. These domains are, from north to south: (i) The Tellian Atlas (knappe domain, composed of sedimentary rocks ranging from the Jurassic to Miocene in age); (ii) The High Plateaus (the foreland of the Alpine range bearing a thin sedimentary cover of Jurassic age). In the western part, there are a series of mountain ranges such as the Saïda Mountains and the Frenda Mountains; (iii) The Saharan Atlas (formed from an elongated trough pinched between the High Plateaus and the Saharan Platform, infilled with a thick sedimentary sequence during the Mesozoic times).

From the palaeogeographic point of view, Alpine Algeria was a part of north-western Africa during the Mesozoic, and was characterized by the individualization of two different paleogeographic domains: the autochthonous intracontinental chains (the Atlas s.s., FRIZON DE LAMOTTE et al,. 2008) and the Rif Range with the Tellian-Kabylian belt (Maghrebides), composed of parautochthonous to allochthonous units (CHALOUAN et al., 2008). The history of these domains is contemporary with the opening of the central Atlantic and Neo-Tethys oceans (BREDE et al., 1992; GOMEZ et al., 2000) during the Late Jurassic, on the southern shelf of Western Tethys (e.g. DERCOURT et al., 1993; BERRA \& ANGIOLINI, 2014). However, the study area was likely to have bathyal water depths (TCHOUMATCHENCO \& KHRISCHEV, 1992).

The Argiles rouges de Kheneg Formation contains the Upper Jurassic marine deposits outcropping in the southern Tell Atlas. These deposits are mostly of pelagic origin, with subordinate yet locally important detrital beds at the mid- Upper Oxfordian 'Grès intercalaires'. In the uppermost Late Oxfordian, intermittent siliciclastic deposits have been described as the Argiles de Saïda facies (subunit C-2 in this study) and interpreted as a result of intra-Oxfordian tectonic movements (ATROPS \& BENEST, 1981). In the Middle Oxfordian to Late Oxfordian, of the Argiles de Saïda Formation in the Saïda Mountains and the Frenda Mountains, the depositional environment was characterized by shallow 


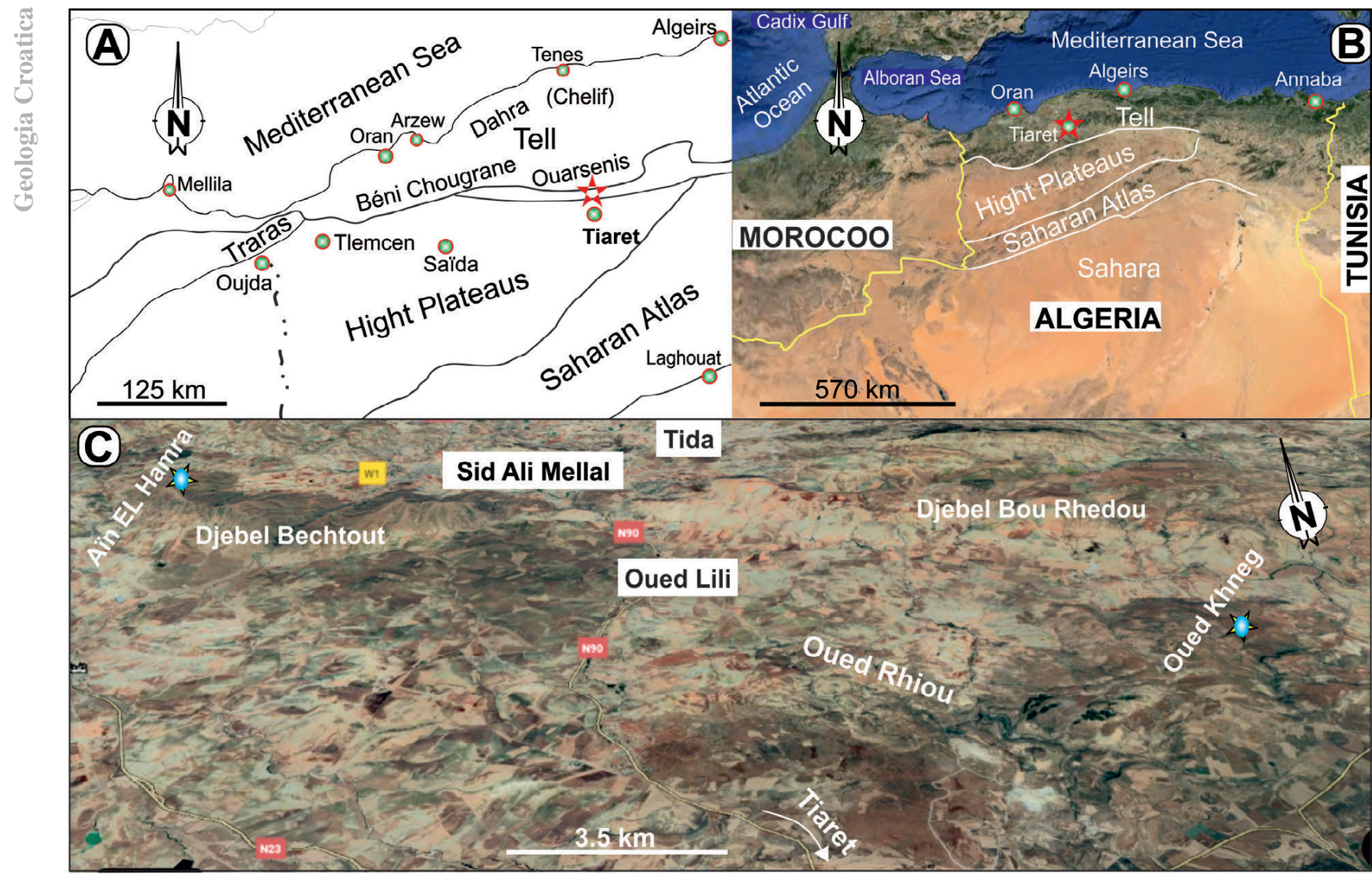

\section{Studied region}

\section{is Studied sections}

Figure 1. Location map of the study area: (A and B) Geographic location and Satellite image of northwestern Algeria; (C) Satellite image of the study area (from Google Earth).

water mixed carbonate-siliciclastic deposition, as evidenced by frequent tidal and tempestite structures (CHERIF et al., 2015, 2018; HALAMSKI \& CHERIF, 2017).

\section{FACIES CHARACTERISTICS AND STRATIGRAPHY}

The Argiles rouges de Kheneg Formation was defined by ATROPS \& BENEST (1994), in order to accommodate a series of marine deposits above the Middle Oxfordian Ammonitico rosso de Frid Formation and overlain by the Kimmeridgian Calcaires du Bou Rheddou Formation. These deposits display a wide array of different lithologies, such as marly and nodular/pseudo-nodular limestones, and bioturbated sandstones. However, the formation can be subdivided into three informal units, based on their respective faunal and lithologic features (corresponding to the facies-type, namely F1-F4) (Fig. 2).

\section{Unit A (Lowermost part of the formation - lower Ammonitico rosso)}

This first unit is up to $25 \mathrm{~m}$ thick in the Aïn El Hamra area, and about $15 \mathrm{~m}$ thick in Oued Kheneg. It consists of the alternation of red claystone /marlstone interlayers (Facies F1) 0.10 to $0.50 \mathrm{~m}$ thick (displaying planktonic foraminifers and ostracods) and red to green nodular limestone (Facies F2), occurring in 0.20 to $3 \mathrm{~m}$ thick packages. Both F1 and F2 commonly contain ammonites, echinoids, crinoids, bivalves and brachiopods. The microscopic scale of F2 (ATROPS \& BENEST, 1984, 1986) shows skeletal and intraclast components with non-skeletal grains (ooids and pellets) forming wackestone and packstone-textured carbonates. The fossil allochems include echinoid debris, crinoid fragments, bivalves, and planktonic foraminifers.

The ammonite communities indicate the Stenocycloides Subzone with Gregoryceras fouquei (KILIAN) and the Grossouvrei Subzone with rare Perisphinctes (Dichotomoceras) bifurcatus (QUENSTEDT) (ATROPS \& BENEST, 1984).

\section{Unit B (Middle part of the formation - middle sandstone)}

This 5-15 m thick unit is easily distinguished from the upper part of the lower unit by the presence of a 0.20 to $1 \mathrm{~m}$ thick sandstone (Facies F3), separated by centimetre thick red to green claystone interlayers. The middle sandstone unit shows a large variation in thickness from $15 \mathrm{~m}$ in the Oued Kheneg section to $5 \mathrm{~m}$ in the Aïn El Hamra section. The sandstone beds are yellow to brown when weathered, grey to greenish in fresh cuts. They show sharp erosive bases, pebble impressions, are channelized (Fig. 3C), and show sole marks (flute-casts). The wave/current structures are usually represented by horizontal and sigmoidal bedding, thick sets of hummocky-cross stratification (HCS) and large wavy cross-bedding (Fig. 3D). Commonly, the beds show unidirectional, linguoid ripple-marks (Fig. 3E) or mega-ripples (Fig. 3F). At the top of this unit, the upper surface of the sandstone is highly bioturbated with large Thalassinoides (Fig. 5D). No body fossils have been recorded in this unit. 


\section{Unit C (Uppermost part of the formation - upper Ammonitico rosso)}

This 40-45 m thick unit is divided into two subunits:

\subsection{Subunit C-1 (lower part of the unit)}

As the lower part of the formation, this $22-30 \mathrm{~m}$ subunit is mostly composed of alternations of interlayered decimetre thick red (rarely green) claystone/marlstone (F1) (0.60-1 m) and red, pink to green micritic limestone (F2) $(0.10-0.20 \mathrm{~m})$. The limestone is nodular to pseudo-nodular and bioturbated. The bioturbation is generally represented by filled burrows. In the lower part, the limestone beds are rich in ammonites, echinoids, crinoids, echinoderm debris, and brachiopods. Broadly, the lithostratigraphic characteristics as well as the fossil content and the microscopic texture are similar to the lower unit.

\section{Subunit C-2 (upper part of the unit)}

This subunit is 12 to $15 \mathrm{~m}$ thick, cropping at the upper part of the Argiles rouges de Kheneg Formation (Fig. 3G). It is mostly composed of green shales to red claystone (F1) and thin sand- and siltstones (Facies F4). F4 embrace fine-grained sandstones (subfacies F4-a) and millimetre to centimetre thick siltstone laminae (subfacies F4-b). The F4-a and F4-b are brown in colour, and are 0.02-0.15 m thick, show channelized and sharp erosive bases, contain septarian nodules (lower part of the succession). The beds display abundant flute-cast, groove-mark, load-cast, horizontal lamination, small scale HCS, unidirectional, wavy and linguoid ripple-marks (Fig. $3 \mathrm{H}$ ).

The unit $\mathrm{C}$ was dated as the Upper Kimmerdgian (Bimammatum Zone, Hypselum Subzone to the Planula Zone, Minutum Subzone) on the basis of ammonites (ATROPS \& BENEST, 1994).
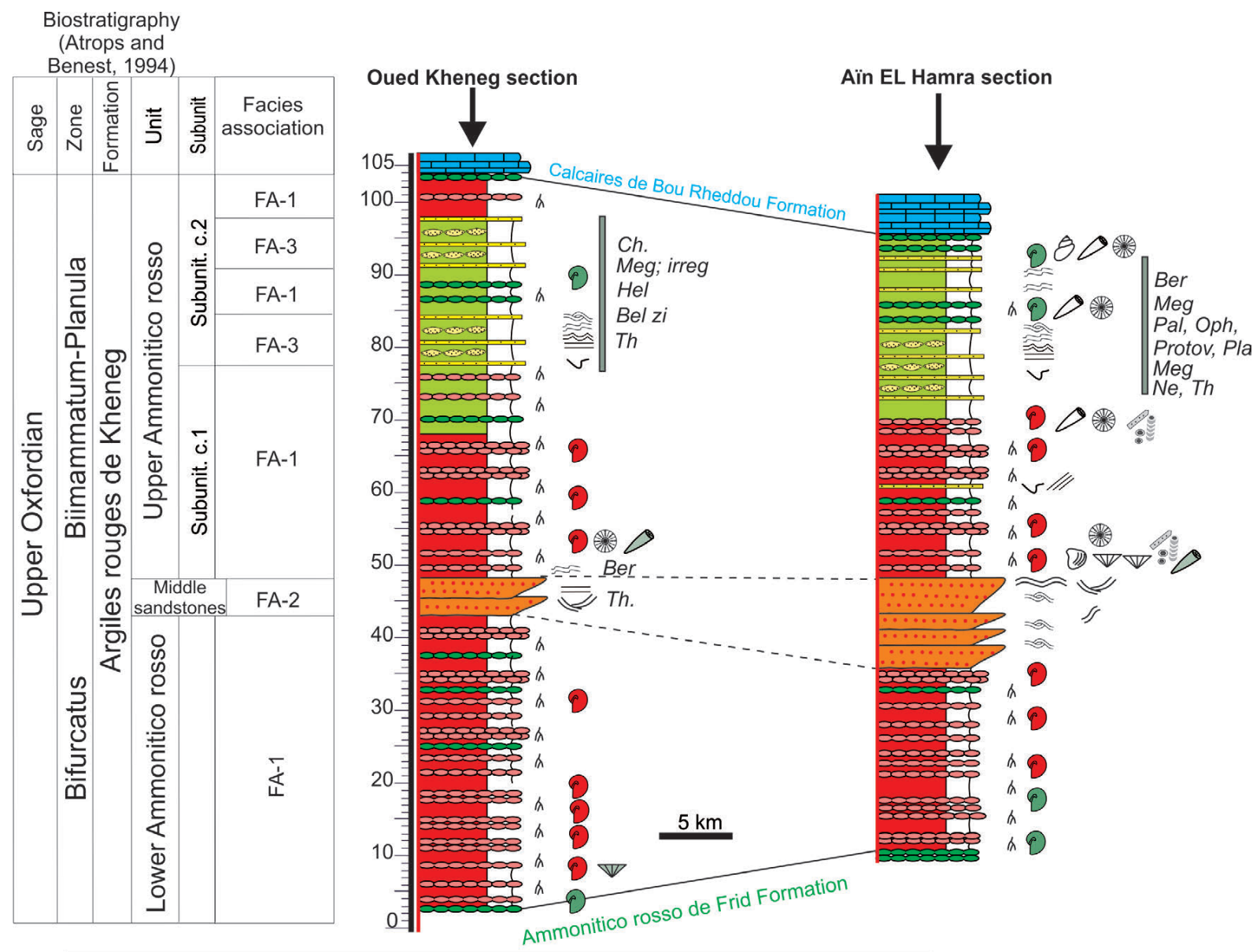

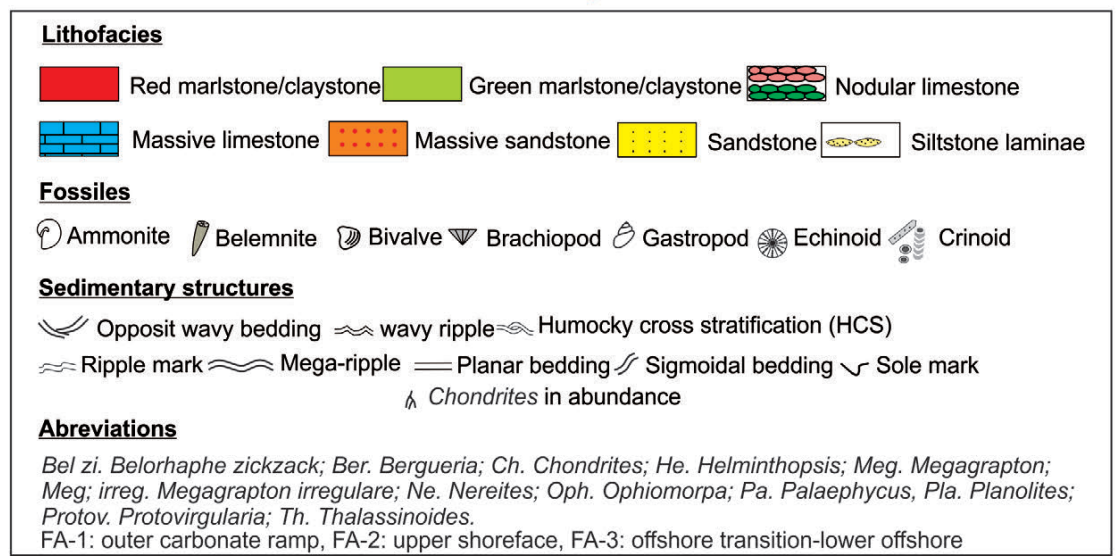

Figure 2. Stratigraphic succession, vertical distribution of trace fossils and facies association inventory of the Upper Oxfordian Argiles rouges de Kheneg Formation (northwestern Algeria). 
Table 1. Distribution of the main facies, ichnogenera and depositional settings.

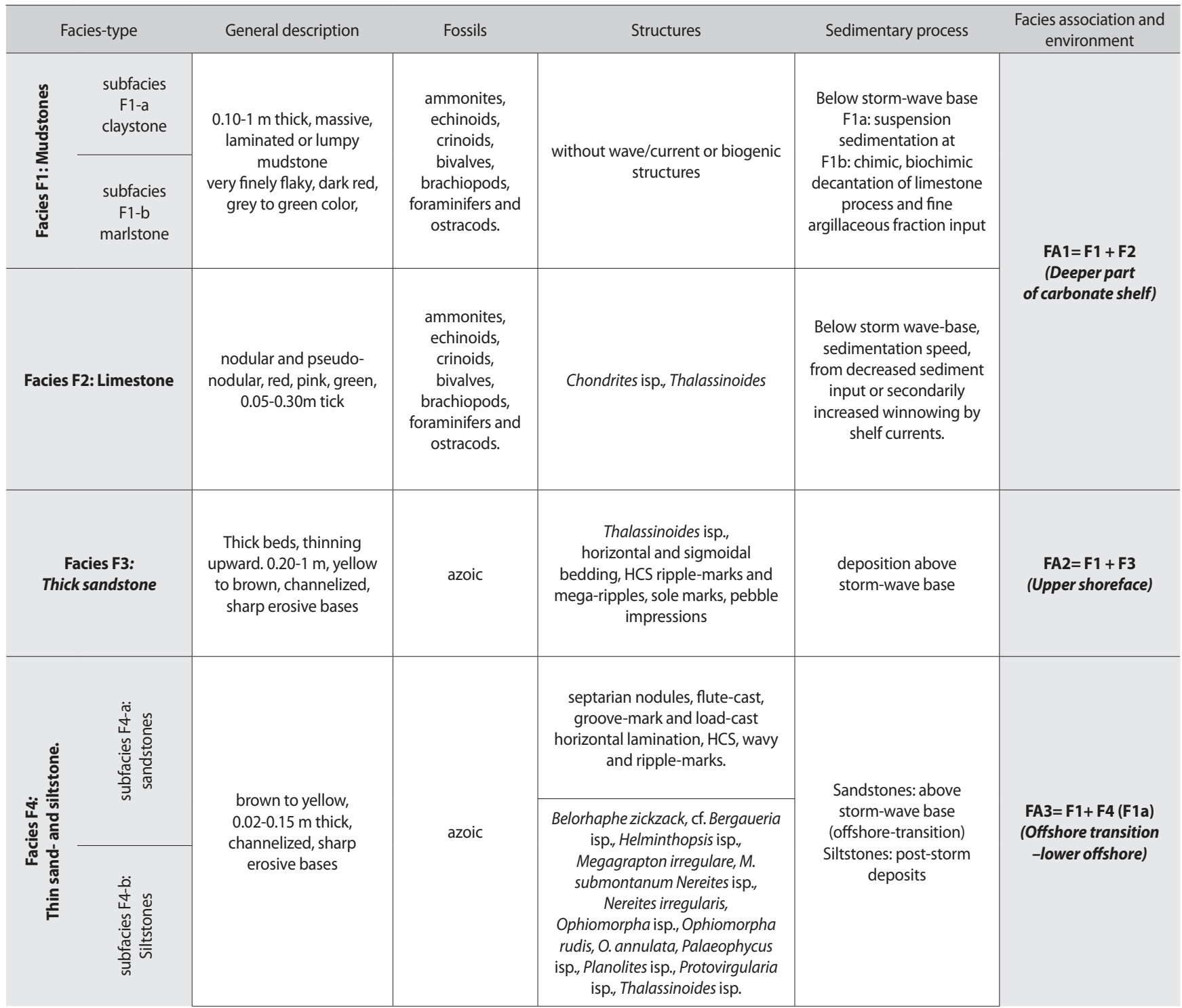

\section{FACIES INTERPRETATION}

The table below summarizes the main facies (F1, F2, F3 and F4) with their principal lithological, sedimentological and ichnological features:

\section{FACIES ASSOCIATION AND PALAEOENVIRONMENT}

Three facies associations have been distinguished, namely FA-1 to FA-3

\subsection{Facies association (FA-1): The deeper part of platform}

FA-1 comprises mudstone facies (F1) and limestone facies (F2), F1 includes red claystone (subfacies F1-a) and marlstone interlayers (subfacies F1-b). F1 and F2 are rhythmically interbedded and correspond to the Ammonitico rosso facies of the lower unit and the subunit C-1 of the upper unit and locally to some parts of the subunit C-2. Sediments of FA-1 were likely deposited in the deeper part of the carbonate shelf.

\subsection{Facies association (FA-2): Upper shoreface}

FA-2 occurs exclusively in the middle unit and is composed of thick sandstone (F3), mostly thinning upward. It contains subordinate thin green claystone interlayers (F1-a). It may be attributed to the upper shoreface deposits and is the shallowest facies of the Argiles rouges de Kheneg Formation.

\subsection{Facies association (FA-3): Offshore transition-lower offshore}

The upper part of the Argiles rouges de Kheneg Formation is composed of the facies association FA-3, which is made of interbedded fine-grained sandstones (F4-a), siltstones (F4-b) and claystone intervals (F1-a) (Fig. 3G). The shallow-water and high-energy conditions are proven by several wave/current sedimentary structures, and the recorded trace fossils belong to the Cruziana ichnofacies-Nereites ichnofacies transition. This facies association represents deposition in offshore transition-lower offshore environments.

\section{ICHNOLOGY}

Trace fossils are abundant and diverse in the subunit C-2 (uppermost part of the formation), but less frequent in the middle sandstone. Fifteen ichnotaxa are recognized, presented in alphabetical order.

\section{Belorhaphe zickzack HEER, 1877 (Fig.4A)}

This trace fossil is hypichnial zigzag and meanders in fine grained sandstones. Most of the zigzags are with an apical angle 

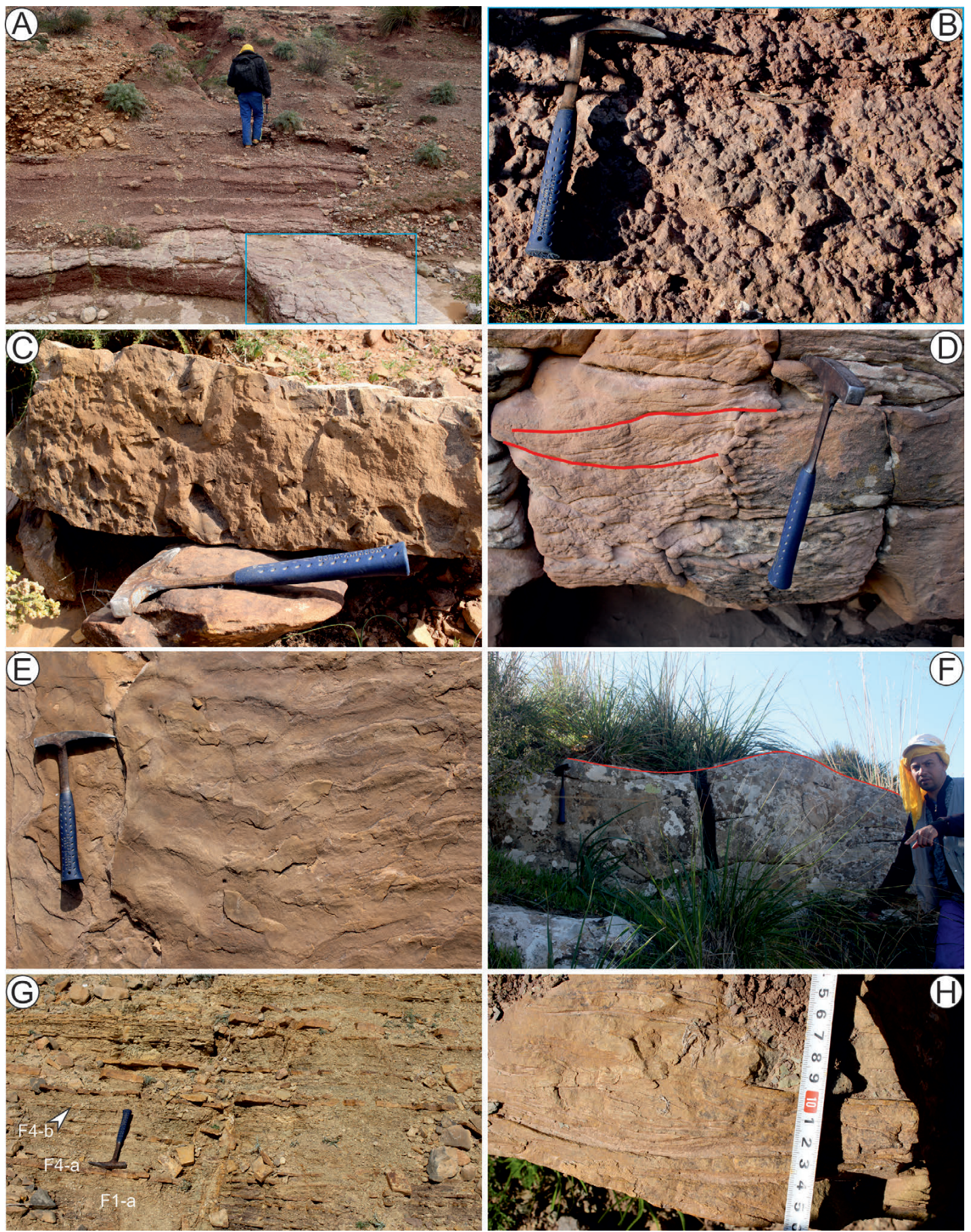

Figure 3. Some sedimentary features of the Argiles rouges de Kheneg Formation. Except the Figures A, B, D, all the illustrations are from the Ain El Hamra section: (A) Ammonitico rosso (facies F2 from the uppermost part of the formation, the Oued Kheneg section), (B) detail of A, showing nodular red limestone, (C) lower bedding surface with pebble impression (middle part of the formation), (D) hummocky-cross stratification (HCS) (middle part of the formation, the Oued Kheneg section), (E) ripple-marks (middle part of the formation), (F) mega-ripples (red line) (middle part of the formation, the Oued Kheneg section), (G) interbedded claystone (F1-a) and thin sandstones (F4-a)/siltstone laminae (F4-b), (H) small scale HCS (subunit C2, upper part of the formation).

of $45^{\circ}, 3 \mathrm{~mm}$ wide and 3-4 mm high. Belorhaphe zickzack is a typical graphoglyptid burrow (SEILACHER, 1977) and occurs in clastic sediments of the deep sea (UCHMAN, 1998; DEMIRCAN \& UCHMAN, 2017).

\section{cf. Bergaueria isp. (Fig. 4B)}

This trace is a hypichnion perpendicular to the stratification plane. It occurs mainly in the upper part of the second and third units. Bergaueria is a cylindrical structure, with an apical depression. It is considered as a resting or dwelling trace, produced by suspension feeders (FÜRSICH, 1975; PEMBERTON et al., 1988) and reported from shallow to deeper marine environments (CRIMES \& ANDERSON, 1985; UCHMAN, 1998; CHERIF et al, 2015).

\section{Chondrites isp. (Fig. 4C)}

This trace is preserved as full relief, composed of a branching dendritic burrow network, mostly horizontal to the bedding. The burrows are from 0.5 to $1 \mathrm{~mm}$ wide, less than $30 \mathrm{~mm}$ long. Chondrites is frequent in the bioturbated limestone of the lower and upper Ammonitico rosso facies. It is considered as a fodinichnion (RICHTER, 1927) of marine annelids (SIMPSON, 1956), 

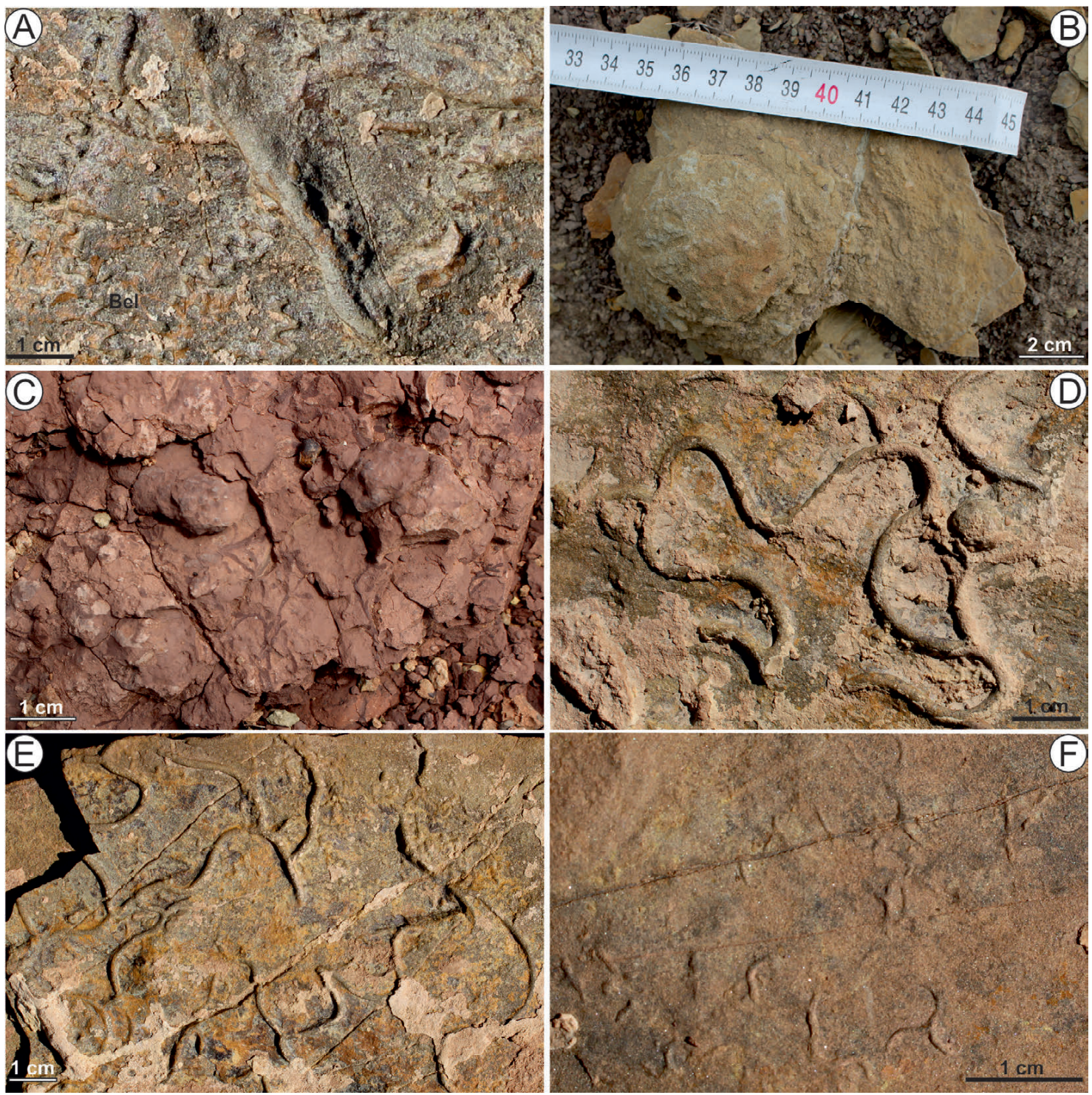

Figure 4. Trace fossils from the subunit $C-2$, upper part of the Argiles rouges de Kheneg Formation: Except for Figures $A$ and $D$, all the traces are from the Oued Kheneg section. (A) Belorhaphe zickzack (Bel) (the Aïn El Hamra section); (B) cf. Bergaueria; (C) Chondrites isp. (arrows) in nodular red limestone; (D) Helminthopsis and unknown trace (Ut) (the Ain El Hamra section); (E) Megagrapton irregulare; (F), Megagrapton submontanum.

and is classified as a chemichnion (BROMLEY, 1996). Generally, Chondrites is reported from offshore (CHERIF et al, 2015, 2018) to deep-sea deposits or in deep tier (BROMLEY, 1990), often considered to be an indicator of anoxia in sediments (BROMLEY \& EKDALE 1984)

\section{Helminthopsis isp. (Fig. 4D)}

This trace is a hypichnial meandering ridge 0.2 to $2 \mathrm{~mm}$ wide and $100 \mathrm{~mm}$ long. It is attributed to polychaete worms (KSIĄŻKIEWICZ, 1977); mostly reported from deeper facies (CHAMBERLAIN; 1971; WETZEL et al., 2007).

\section{Megagrapton irregulare KSIĄŻKIEWICZ, 1968 (Fig. 4E)}

This trace fossil is preserved as a system of hypichnial, winding branched semi-cylindrical ridges forming an irregular net. The ridges are 1-2 mm wide, the branching points are 30-150 $\mathrm{mm}$ apart. $M$. irregulare has been observed in deposits of a wide spectrum of environments (BUATOIS et al., 2017), but is considered to be typical of turbiditic deposits (KSIĄŻKIEWICZ, 1977; UCHMAN, 1998).
Megagrapton submontanum AZPEITIA MOROS, 1933 (Fig. 4F)

These are hypichnial, winding branched ridges forming net with meshes bordered by strings, which are $1.0-1.7 \mathrm{~mm}$ wide and about four meshes are preserved. The maximum width of the mesh is 30 and $50 \mathrm{~mm}$. M. submontanum occurs exclusively in deep water, mainly in flysch deposits (UCHMAN, 1998).

Nereites isp. (Fig. 5A)

This is a set of hypichnial horizontal, meandering ribbons, 2.0-5.0 $\mathrm{mm}$ wide, bounded by an even zone which is $1-2 \mathrm{~mm}$ wide.

Nereites irregularis SCHAFHÄUTL, 1851 (Fig. 5B)

This trace is preserved as an epichnial meandering burrow, made of a shallow furrow, 4-5 mm wide. Nereites are locomotion traces of annelid worms (SEILACHER, 2007), commonly occurring in deep-sea deposits. It is composed of a median faecal string and bounding zones, which indicate sediment reworking (UCHMAN, 1995). 

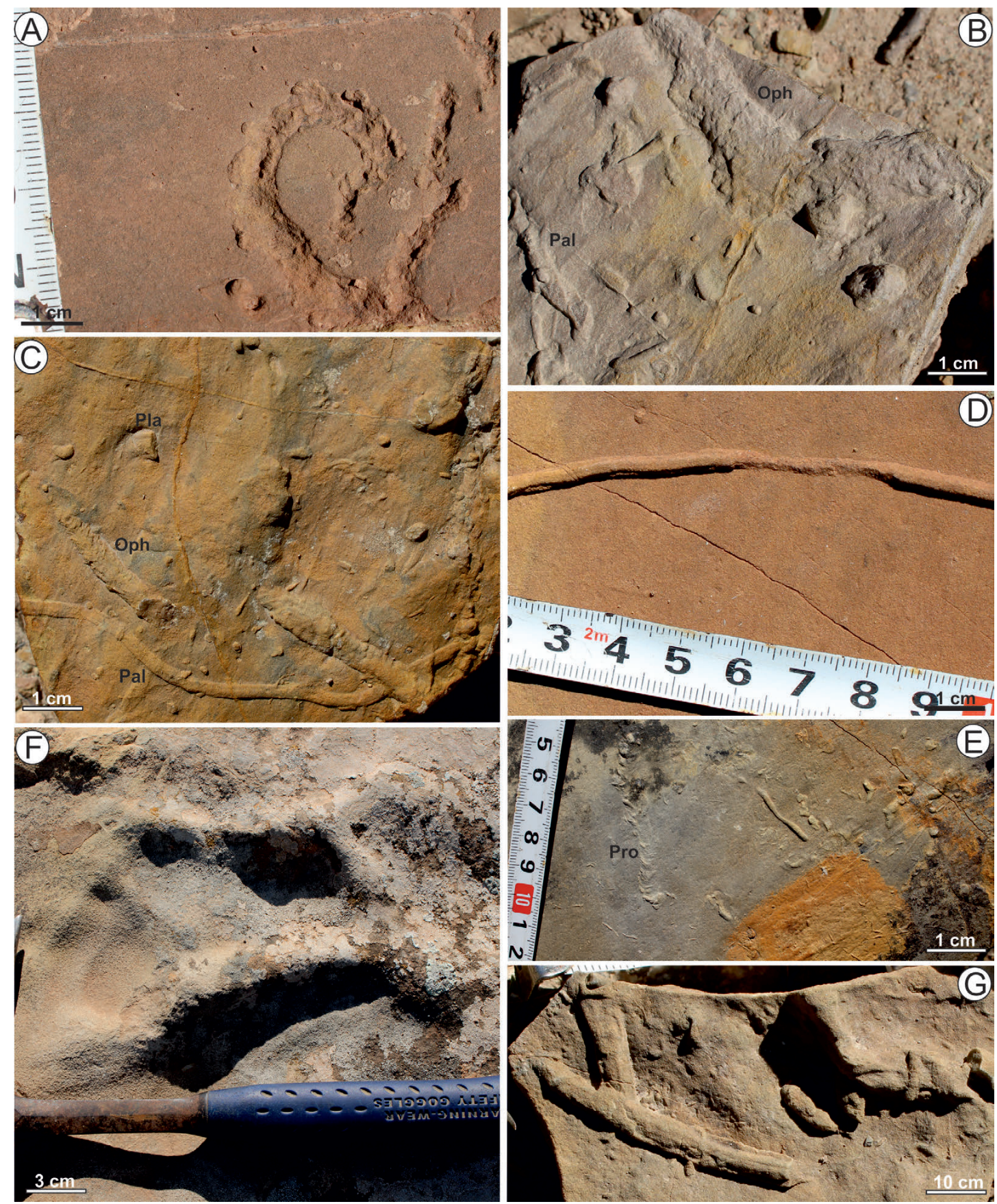

Figure 5. Following on from Figure. 4: Except for Figures B and G, all the traces are from the Oued Kheneg section, with (A) Nereites isp.; (B) Nereites irregularis (the Ain El Hamra section), (C) Ophiomorpha isp. (Oph), Planolites isp. (Pla), (D) cf Ophiomorpha annulta (Opha) and Ophiomorpha rudis (Ophr), Palaeophycus isp. (Pal) and Planolites isp. (Pla), (E) Palaeophycus isp. (F) Protovirgularia isp. (Pro) and another set of small to very small burrows (arrows) in the sole of fine grained saindstone, (G) large size Thalassinoides isp. (middle sandstone unit, the Aïn El Hamra section), (H) Thalassinoides isp. (Th) and Planolites isp. (Pla) on the top of fine grained sandstone.

\section{Ophiomorpha isp. (Fig. 5C)}

This consists of a horizontal, cylindrical burrow 5 to $10 \mathrm{~mm}$ wide, and at a least of $70 \mathrm{~mm}$ long, covered by irregular pellets and co-occurs with Planolites.

cf. Ophiomorpha annulata KSIĄŻKIEWICZ, 1977 (Fig. 5D) occurs as a straight to slightly curved, horizontal tunnel, preserved in epirelief, on the sandstone bed, 2.5-8 $\mathrm{mm}$ in diameter, and about $250 \mathrm{~mm}$ long. O. annulata maybe smooth or showing arranged granules as a meniscate shape.

\section{Ophiomorpha rudis KSIĄŻKIEWICZ, 1977 (Fig. 5D)}

It co-occurs with Palaeophycus and Planolites as simple cylindrical burrows, straight or slightly curved, horizontal to bed- ding plane. This trace is $2.5-5 \mathrm{~mm}$ wide on average and $300 \mathrm{~mm}$ long, showing scratches or small to strong nodular external surfaces. Ophiomorpha is produced by shrimp-like crustaceans, living in burrows made in high-energy coastal marine sand environments (FREY et al., 1978), but it has also been reported from deep-sea deposits (KERRN \& WARME, 1974; UCHMAN, 1995; UCHMAN, 2009).

\section{Palaeophycus isp. (Fig. 5C-D and E)}

Slightly sinusoidal horizontal and unbranched cylindrical burrows, 5 to $10 \mathrm{~mm}$ in diameter, a few centimetres to 150-200 mm-long; studied specimens are preserved as positive/negative epi- or hyporeliefs. This trace characterizes mainly the upper part 
of the third unit. Palaeophycus is an extremely eurybathic faciescrossing trace, interpreted as a mostly dwelling burrow of suspension feeding or predatory worms (PEMBERTON \& FREY, 1982).

\section{Planolites isp. (Fig. 5C-D and H)}

A straight, gently curved cylindrical burrow, preserved mostly as hypichnial ridges which are $2-4 \mathrm{~mm}$ wide and about $8.0 \mathrm{~mm}$ long. They are found solitarily or in association with Ophiomorpha, Palaeophucys and Thalassinoides. Planolites is attributed to vermiform deposit-feeders (PEMBERTON \& FREY, 1982; UCHMAN, 1995) and considered as facies-crossing from distal platforms (DAM, 1990; CHERIF et al, 2015) to deepsea deposits (DEMIRCAN, 2008).

\section{Protovirgularia isp. (Fig. 5F)}

Protovirgularia occurs as horizontal cylindrical straight trail preserved as epirelief, $2.5 \mathrm{~mm}$ in diameter, with regular to irregular chevron-shaped markings. This trace is commonly attributed to fodinichnia and cubichnia of molluscs such as bivalves and it has been documented in estuarine deposits and wave-influenced deposits (MANGANO \& BUATOIS, 2004; UCHMAN \& GAZDZICKI, 2006; CHERIF et al, 2015, 2018).

\section{Thalassinoides isp. (Fig. 5G-H)}

Thalassinoides consists of horizontal, sub-cylindrical systems of irregular burrows, generally dichotomous, Y-shaped branching. All specimens are preserved as full-relief structures. Burrow diameter ranges from 4 to $50 \mathrm{~mm}$, they are 50 to $250 \mathrm{~mm}$ long. Thalassinoides is a facies-crossing ichnogenus, representing deposit-feeding and dwelling activities of crustaceans (FÜRSICH, 1973), reported from shallow-marine (SCHLIRF, 2000, CHERIF et al, 2015, 2018) to deep-marine (UCHMAN, 1995) environments.

\section{DISCUSSION AND CONCLUSIONS}

Three main facies associations (FA-1 to FA-3) occur in the Oxfordian Argiles rouges de Kheneg Formation in northwestern Algeria. Two facies (FA-2 and FA-3) associations characterize shelf environments from the shallowest (FA-2) to deeper ones (FA-3), while FA-1 could be interpreted as the deepest part of the shelf, attributed to the intra-Oxfordian tectonic movements (BENEST \& ATROPS, 1998; CHERIF et al., 2015). The transition from FA-1 (lower Ammonitico rosso unit) to FA-2 (middle sandstone unit) have been interpreted as an intermittent sandstone discharge caused by tectonic instability. The passage from FA-1 to FA-3 was attributed to an important SW current provenance of clastic influx, infilling and reducing the bathymetry, namely the Argiles de Saïda facies (ATROPS \& BENEST, 1984). Such evolution is indicated by stratal colour variations and attributed to temporal changes in sediment composition (e.g., clastic vs. carbonate content, SAVRDA, 2007). Hence, the Oxfordian Argiles rouges de Kheneg Formation is characterized by a diverse trace fossil association (15 ichnotaxa), occurring in a wide range of marine environments (i.e. Bergaueria, Ophiomorpha, Palaeophycus, Planolites, Thalassinoides). However, deep water traces or predominantly deep water traces (i.e. Belorhaphe, Chondrites, Helminthopsis, Nereites, Megagrapton) are also diverse and abundant in the Argiles rouges de Kheneg Formation, indicating that this part of the formation was deposited under deep water conditions. They are interpreted as the Cruziana ichnofacies- $\mathrm{Ne}$ - reites ichnofacies transition, and the absence of the typical turbiditic sequence excludes the really deep flysch deposits, whereas the frequent wavy/storm structures could correspond to the offshore transition-lower offshore environment.

In well-oxygenated substrates, the ichnofossil component is characterized by high diversity assemblages that contain forms of large diameter up to several centimetres (SAVRDA, 2007). The presence of infaunal communities and traces of their activities is dependent on bottom-water oxygenation. The less diverse bioturbation is related to lower oxygen concentrations (e.g., RHOADS AND MORSE, 1971; SAVRDA et al., 1984). Therefore, the occurrence of Chondrites without the other trace fossils in the Ammonitico rosso facies (F2) from the lower and upper part of Argiles rouges de Kheneg Formation have been regarded as an indicator of the low oxygen concentrations in bottom waters (BROMLEY \& EKDALE, 1984; SAVRDA and BOTTJER, 1989; WIGNALL, 1991), or dysoxic conditions representing a probably pipe zone (SAVRDA, 2007) in deep water sediments during particular time intervals. It can also occur in well oxygenated deposits in deep tier, where oxygenation of pore waters is already low. The intense bioturbation in the uppermost part of the Argiles rouges de Kheneg Formation may be attributed to the increasing supply and higher food availability caused by oxygen levels related to storm events.

Definite shallow water traces are only represented by Protovirgularia. This is somewhat surprising considering the occurrence of shallow water facies in the Argiles rouges de Kheneg Formation.

\section{ACKNOWLEDGEMENT}

We thank Pr. Bhawanisingh G. DESAI (School of Petroleum Technology, Pandit Deendayal Petroleum University, Gandhinagar, India) for his help in the determination of trace fossils. We are grateful to the reviewers, Pr. Alfred UCHMAN and anonymous reviewer for their constructive comments of the manuscript.

\section{REFERENCES}

ATROPS, F. \& BENEST, M. (1981): Données biostratigraphiques nouvelles sur l’Oxfordien et Kimméridgien du Djebel Nador et Tiaret (Avant-pays tellien, Algérie): Conséquences paléogéographiques.- Geobios, 1/14, 155-122. doi: 10.1016/ S0016-6995(81)80170-2

ATROPS, F. \& BENEST, M. (1994): Les formations à ammonites du Malm dans le bassin tellien, au nord de Tiaret: leur importance pour les corrélations avec les séries de l'avant-pays de l'Ouest algérien.- In: CARIOU, E. \& HANTZPERGUE, P. (eds.): 3rd International Symposium on Jurassic stratigraphy, Poitiers, 1991.- Geobios, 79-91. doi : 10.1016/S0016-6995(94)80127-4

AUGIER, C. (1967): Quelques éléments essentiels de la couverture sédimentaire des Hauts Plateaux.- Publication du Service Géologique de l'Algérie, 34, 47-80.

AZPEITIA MOROS, F. (1933) : Datos para el estudio paleontólogico del Flysch de la Costa Cantábrica y de algunos otros puntos de España.- Boletín del Instituto Geológico y Minero de España, 53, 1-65.

BAUCON, A., BEDNARZ, M., DUFOUR, S., FELLETTI, F., MALGESINI, G., DE CARVALHO, CN., NIKLAS, KJ., WEHRMANN, A., BATSTONE, R., BERNARDINI, F., BRIGUGLIO, A., CABELLA, R., CAVALAZZI, B., FERRETTI, A., ZANZERL, H., MCILROY, D. (2019): Ethology of the trace fossil Chondrites: form, function and environment.- Earth-Science Reviews, 202. doi: 10.1016/j. earscirev.2019.102989

BENEST, M., OUARDAS, T., PERRIAUX, J \& USELLE, JP. (1998): Dynamique et contrôle de la sédimentation détritique de l’Oxfordien supérieur ou Kimméridgien supérieur (Zone à Acanthicum) dans le cadre paléostructurale de la plate-forme ouest algérienne.- Bulletin su service Géologique de l'Algérie, 9/2, 95-121.

BERRA, F. \& ANGIOLINI, L. (2014): The evolution of the Tethys region throughout the Phanerozoic: A brief tectonic reconstruction.- In: MARLOW, L., KENDALL, C. \& YOSE, L. (eds.): Petroleum systems of the Tethyan region.-American Association of Petroleum Geologists Memoir, 106, 1-27. doi: 10.1306/13431840M1063606 
BOTTJER, DJ., DROSER, ML. \& JABLONSKL, D. (1987): Bathymetric trends in the history of trace fossils.- In: BOTTJER DJ. et al. (eds.): New concepts in the use of Biogenic sedimentary structures for Palaeoenviromental Interpretation.-SEPM, 3Dcifi Section, Los Angeles, 57-65.

BREDE, R., HAUPTMANN, M. \& HERBIG, H-G. (1992): Plate tectonics and the intracratonic mountain ranges in Morocco-TheMesozoic-Cenozoic development of the Central High Atlas and the Middle Atlas.- Geologische Rundschau, 81, 127-141.

BROMLEY, RG. (1990): Trace fossils. Biology and Taphonomy.- Special Topics in Palaeontology Series. London, Boston, Sydney, Wellington: Unwin Hyman, 280 p.

BROMLEY, RG. (1996): Trace fossils. Biology, taphonomy and applications.- Chapman \& Hall, London, 361 p.

BROMLEY, R.G. \& EKDALE, A.A. (1984): Chondrites: a trace fossil indicator of anoxia in sediments.- Science, 224(4651), 872-874. doi: 10.1126/science.224.4651.872

BUATOIS, L.A., WISSHAK, M., WILSON, M.A. \& MANGANO, M.G. (2017): Categories of architectural designs in trace fossils: a measure of ichnodisparity.- EarthScience Reviews, 164, 102-181. doi: 10.1016/j.earscirev.2016.08.009

CARATINI, C. (1970): Etude géologique de la région de Chellala-Reibell.- Publication du Service Géologique de l'Algérie, 40/21, $311 \mathrm{p}$

CHALOUAN, A., MICHARD, A., EL KADIRI, KH., NEGRO, F., FRIZON DE LAMOTTE, D., SOTO, J.I. \& SADDIQI, O. (2008): The Rif Belt.- In: MICHARD, A., SADDIQI, O., CHALOUAN, A. \& FRIZON de LAMOTTE, D. (eds.): Continental Evolution: The Geology of Morocco Structure, Stratigraphy, and Tectonics of the Africa Atlantic-Mediterranean Triple Junction. Lecture Notes in Earth Sciences, Springer, Berlin Heidelberg, 116, 203-302. doi: 10.1007/978-3-540-770763_5

CHERIF, A., BENYOUCEF, M., FERRÉ, B., ET BENHAMOU, M. (2018): Etude sédimentologique et ichnologique de la Formation des Argiles de Saïda (Jurassique supérieur) dans les monts de Frenda (Algérie nord-occidentale).- Revue de Paléobiologie, Genève, 37 (1).

CHERIF, A., BERT, D., BENHAMOU, M. \& BENYOUCEF, M. (2015): La Formation des Argiles de Saïda (Jurassique supérieur) dans le domaine tlemcenien oriental (Takhemaret, Algérie): données biostratigraphiques, ichnologiques et sédimentologiques.- Revue de Paléobiologie, Genève, Suisse, 34/2, 363-384.

CRIMES, TP. \& ANDERSON, MM. (1985): Trace fossils from Late Precambrian Early Cambrian strata of southeastern Newfoundland (Canada): temporal and environmental implications.- Journal of Paleontolology, 59, 310-343.

DAM, G. (1990): Palaeoenvironmental significance of trace fossils from the shallow marine Lower Jurassic Neill Klinter Formation, East Greenland.- Palaeogeography, Palaeoclimatology, Palaeoecology, 79, 221-248. doi: 10.1016/00310182(90)90019-4

DEMIRCAN, H. (2008): Trace fossil associations and palaeoenvironmental interpretation of the late Eocene units (SW-Thrace).- Bulletin of the Mineral Research and Exploration (MTA) of Turkey, 136, 29-47.

DEMÍRCAN, H \& UCHMAN, A. (2017): Short distance variability of trace fossils in submarine slope and proximal basin plain deposits: a case study from the Ceylan Formation (upper Eocene), Gelibolu Peninsula, NW Turkey.- Bollettino della Società Paleontologica Italiana, 56/2, 253-275.

DERCOURT, J., RICOU, L.E., \& VRIELYNCK, B. (eds.) (1993): Atlas Tethys Palaeoenvironmental Maps.- Commission de la Carte géologique du monde, Gauthier-Villars, Paris, $307 \mathrm{p}$.

ELMI, S. \& BENEST, M. (1978): Les «Argiles de Saïda », faciès flyschoïde du Callovo-Oxfordien du sillon tlemcénien (Ouest algérien): stratonomie, environnement, interprétation et évolution paléogéographique.- Livre Jubilaire Jacques Flandrin, Document des Laboratoires de Géologie, Lyon, 4, 203-261.

FENET, B. (1975): Recherche sur l'alpinisation de la bordure septentrionale du Bouclier africain à partir de l'étude d'un élément de l'orogène nord-magrébien: les Monts du Djebel Tessala et les Massifs du littoral oranais.- Thèse Ès-Sciences, Université de Nice, $301 \mathrm{p}$.

FREY, R.W., HOWARD, J.D. \& PRYOR, W.A. (1978): Ophiomorpha: its morphologic, taxonomic, and environmental significance.- Palaeogeography, Palaeoclimatology, Palaeoecology, 23, 199-223. doi: 10.1016/0031-0182(78)90094-9

FRIZON DE LAMOTTE, D., LETURMY, P., MISSENARD, Y., KHOMSI, S., RUIZ, G., SADDIQI, O., GUILLOCHEAU, F. \& MICHARD, A. (2009): Mesozoic and Cenozoic vertical movements in the Atlas system (Algeria, Morocco, Tunisia): an overview.- Tectonophysics, 475, 9-28.

FÜRSICH, F.T. (1973): A revision of the trace fossils Spongeliomorpha, Ophiomorpha and Thalassinoides.- Neues Jahrbuchfür Geologie und Paläontologie, Monatshefte, 719-735.

FÜRSICH, F.T. (1975): Trace fossils as environmental indicators in the Corallian of England and Normandy.- Lethaia, 8, 151-172. doi: 10.1111/j.1502-3931.1975. tb01309.x
GOMEZ, F., BEAUCHAMP, W. \& BARAZANGI, M. (2000): Role of the Atlas Mountains (northwest Africa) within the African Eurasian plate-boundary zone.- Geology, 28/9, 775-778. doi: 10.1130/0091-7613(2000)028\%3C0775:ROTAMN\%3 E2.3.CO;2

HALAMSKI, A.T. \& CHERIF, A. (2017): Oxfordian brachiopods from the Saïda and Frenda mountains (Tlemcenian Domain, north-western Algeria).- Annales Societatis Geologorum Poloniae, 87, 141-156. doi: 10.14241/asgp.2017.006

KERRN, JPH. \& WARME, JE. (1974): Trace fossils and bathymetry of the Upper Cretaceous Point Loma Formation, San Diego, California.- Bulletin of Geologic Society of America, 85, 893-900. doi: 10.1130/0016-7606(1974)85\%3C893:TFAB OT\%3E2.0.CO;2

KSIĄŻKIEWICZ, M. (1968): O niektórych problematykach z flszu Karpat polskich, Część III. (On some problematic organic traces from the Flysch of the Polish Carpathians. Part 3).- Rocznik Polskiego Towarzystwa Geologicznego, 38, 3-17.

KSIAZKIEWICZ, M. (1977): Trace fossils in the flysch of the Polish Carpathians.- Palaeontology Polonica, 36, 1-200.

MALPAS, J.A., GAWTHORPE, R.L., POLLARD, J.E. \& SHARP, I.R. (2005): Ichnofabric analysis of the shallow marine Nukhul Formation (Miocene), Suez Rift, Egypt: implications for depositional processes and sequence stratigraphic evolution.- Palaeogeography, Palaeoclimatology, Palaeoecology, 215, 239-264. doi: 10.1016/j.palaeo.2004.09.007

PEMBERTON, G.S., FREY, R.W. \& BROMLEY, R.G. (1988): The ichnotaxonomy of Conostichnus and other plug-shaped. ichnofossils.- Canandian Journal of Earth Sciences, 25, 866-892.

POLVECHE, J. (1960) : Contribution à l'étude géologique de l'Oranais.- Publication du Service de la Carte géologique, 24, 96 p.

RICHTER, T. (1927): Die fossilen Fährten und Bauten der Würmer, ein Überblick über ihre biologischen Grundformen und deren geologische Bedeutung.- Paläont Z, 9, 193-240.

RHOADS, D.C. \& MORSE, J.W. (1971): Evolutionary and ecologic significance of oxygen-deficient basins.- Lethaia, 4, 413-428. doi: 10.1111/j.1502-3931.1971. tb01864.x

SAVRDA, C.E. (2007): Trace Fossils and Marine Benthic Oxygenation.- In: MILLER III W. (ed.): Trace Fossils, Concepts, Problems, Prospects. Elsevier, Arcata, 149-156. doi: 10.1016/B978-044452949-7/50135-2

SAVRDA, C.E. \& BOTTJER, D.J. (1989): Trace fossils model for reconstructing oxygenation histories of ancient marine bottom waters: application to Upper Cretaceous Niobara Formation, Colorado.- Palaeogeography, Palaeoclimatology, Palaeoecology, 74, 49-74. doi: 10.1016/0031-0182(89)90019-9

SAVRDA, C.E., BOTTJER, D.J. \& GORSLINE, D.S. (1984): Development of a comprehensive oxygen-deficient marine biofacies model: evidence from Santa Monica, Santa Barbara, and San Pedro basins, California continental borderland.- American Association of Petroleum Geologists Bulletin, 68, 1179-1192.

SCHAFHÄUTL, K.E. (1851): Geognostische Untersuchungen des südbayerischen Alpengebirges Literarischartistische-Anstalt, München, p. 208.

SCHLIRF, M. (2000): Upper Jurassic trace fossils from the Boulonnais (Northern France).- Geologica et Palaeontologica, 34, 145-213.

SEILACHER, A. (1977): Pattern analysis of Paleodictyon and related trace fossils.- In: Crimes, T.P. \& HARPER, J.C. (eds.): Trace fossils 2. Geological Journal, Special Issue, 9, 289-334.

SEILACHER, A. (2007): Trace fossil analysis.- Springer, New York, 226 p.

SIMPSON, S. (1956): On the trace-fossil Chondrites.- Quarterly Journal of the Geological Society, 112, 21-24, London. doi: 10.1144/GSL.JGS.1956.112.01-04.23

TCHOUMATCHENCO, P. \& KHRISCHEV, KH. (1992): Le Jurassique dans les Monts de Tiaret et de 1'Ouarsenis occidental (Algérie).- Geologica Balcanica, 22/5, 29-39.

UCHMAN, A. (1995): Taxonomy and palaeoecology of flysch trace fossils: He Marnoso-arenacea Formation and associated facies (Miocene, Nortern Apennines, Italay).Beringeria, 15, 1-115.

UCHMAN, A. (1998): Taxonomy and ethology of flysch trace fossils: revision of the Marian Ksiăzkiewicz collection and studies of complementary material.-Ann Soc Geol Polon, 68,105-218.

UCHMAN, A. \& GAŹDZICKI, A. (2006): New trace fossils from the La Meseta Formation (Eocene) of Seymour Island, Antarctica.- Polish Polar Research 27/2, 153-170.

UCHMAN, A. (2009): The Ophiomorpha rudis ichnosubfacies of the Nereites ichnofacies: characteristics and constraints.- Palaeogeography, Palaeoclimatology, Palaeoecology, 276, 107-119. doi: 10.1016/j.palaeo.2009.03.003

WELSCH, J. (1890): Les terrains secondaires des environs de Tiaret et de Frenda (Département d’Oran, Algérie). Thèse présentée à la Faculté des Sciences de Paris pour obtenir le grade de docteur s-sciences naturelles.-Série A, no 139; no d'ordre 692. Le Bigot Frères, Lille, 204 p.

WIGNALL, P.B. (1991): Dysaerobic trace fossils and ichnofabrics in the Upper Jurassic Kimmeridge Clay of southern England.-Palaios, 6, 264-270. doi: 10.2307/3514906 
